\title{
ALTERNATIVE RELIGION IN PRETORIA Part II: East comes South
}

\author{
Michel Clasquin \\ University of South Africa
}

\section{Abstract}

This article is part of a larger research project on patterns of religious pluralism in the city of Pretoria, and is based on field research conducted in the period 1993-1995 by the author, Prof JS Krüger and Mr MS (Victor) Molobi. Material extraneous to the main thrust of the project is being published in a series of articles. This article describes the rise of alternative religious forces in Pretoria during the late nineteenth and early twentieth centuries and how these faiths have accommodated to the religious environment of the city. Part I dealt with those groups that, while perhaps unorthodox, still base themselves on the Christian tradition and ethos. Part II takes a look at a different and new influence, namely those traditions new to the city that base themselves at least partly on Eastern thinking, namely Theosophy, Freemasonry, Rosicrucianism, Spiritualism, Christian Science and the Liberal Catholic Church.

\section{Introduction}

At the time when the alternative forms of Christianity were settling in Pretoria, another group of faiths also made its appearance. Like the groups discussed in Part I of this article, they had originated in nineteenth century America, or in a few cases, Europe. Although some of them, like the Masons and the Rosicrucians, claim a far longer prehistory, it can fairly be said that the nineteenth century was formative for these groups, as this is when they first started to have an influence on the population at large, when they first began to have a global impact. Accordingly, they still display something of the religious ferment of that century, which was far from the staid and static period that we who live afterwards would sometimes like to see it as. From Swedenborgians to Transcendentalists, from Universalists to Positivists, nineteenth century western society saw an unprecedented fascination with the occult, the mysterious and the exotic, a fascination that has continued into the twentieth century with the rise of the New Age and Neo-Paganism and looks set to continue further into the twenty-first.

Much of the impetus for this development came from the west's new colonies in Asia. Reports by travellers and missionaries were widely circulated, and early translations of Indian and Chinese sacred texts began to appear. This had a profound influence on many of the movements discussed in this article. In some, like Theosophy, the link is clear and explicitly stated. In others, it is more vague. But they all put forward an eastern-inspired, or at least eastern-looking view of the world that contradicts and counteracts the hard, mechanistic worldview of nineteenth century science. They posit a world in which the mind, be it human or divine, can directly affect human beings and their world. This does not imply that they are 'Eastern' religions in quite the same sense as orthodox Hinduism or Buddhism. Indeed, some of them regard themselves as being squarely within the Christian tradition, even if other, more conventional, Christians dispute this self-image. Examples of these include the Liberal Catholic Church, Spiritualist Church and Christian Science'.

1. The correct name for this church is 'Church of Christ, Scientist'. We elect to refer to the movement as 'Christian Science' and the 'Christian Science church', however, mainly for stylistic reasons. 
Christian Science, in fact, is something of an anomaly. It defies our classificatory system by showing aspects of both the movements discussed in Part I of this article and of those that clearly belong here in Part II. Like the Jehovah's Witnesses, it uses a centralised and uniform system of teaching in which all adherents worldwide will receive the same message on any given Sunday, sent out from its world headquarters in Boston. But it shows far fewer of the authoritarian traits so common among the conservative nineteenth century alternative movements. It is less influenced by Eastern religious thinking and more explicitly Christian than most, if not all, of the other groups described here, but shares with them not only a common point of origin, but also a certain 'liberal' religious ethos, an ethos which is expressed in matters such as a refusal to condemn religious teachings other than their own and in the prominent role played by women.

For this reason, we have described it in Part I as a 'transitional' form and deferred further discussion until we came to its inclusion in this section. This requires further explanation. We are not saying that Christian Science descended from one of the movements described in Part I, nor that one of the other movements described here descended from it. What 'transitional' means in this context is that Christian Science shows attributes of both these streams of Western religious creativity in the nineteenth century. Our inability to fit it into a neat pigeon-hole does not indicate a lack of development on the side of Christian Science. Instead, it shows up the shortcomings of our classificatory system ${ }^{2}$. Its inclusion in Part II of this article should not be regarded as a value-judgement on our part.

\section{Freemasons and Co-Masons}

Freemasonry, was one of the earliest alternative forms of spiritual expression present in Pretoria. There are two Masonic lodge buildings ${ }^{3}$ in Pretoria, one in the city centre, on Van der Walt Street, and one in The Willows, in the city's affluent eastern suburbs. These two buildings are, however, shared by 26 lodges. These lodges operate under different Masonic constitutions, namely those of England, Scotland, Ireland and South Africa. In other South African cities, there are also lodges exclusively for members of specific immigrant communities: there is, for instance, an active Dutch-speaking Masonic movement.

Freemasonry has a long history - it claims to have been founded before 1598 and looks back to a prehistory among the cathedral builders (hence 'Masons') of medieval Europe. The Grand Lodges of England and Scotland were founded in 1716 and 1736, respectively. Masonry has also exercised a wider influence: our respondent indicated that Lord Baden-Powell was a Freemason, and that the Boy Scout movement which he founded incorporated certain Masonic elements. Elsewhere, one could note the many Masonic symbols on US printed currency, such as the sheaf of wheat and the all-seeing eye in the pyramid, and indeed many of the framers of the US constitution were Freemasons.

The Grand Lodge of Southern Africa is a relative newcomer, having been established only in 1961 during a dispute over the status of the grand lodge of the Netherlands ${ }^{4}$, but Freemasonry under one constitution or another has been practised in South Africa since 1772. Precise dates for the arrival of Freemasonry in Pretoria cannot be established, but all

2. As was the case in Part I, this 'cluster' of religious organisations is one of our devising and is based on both historical and theological/philosophical considerations. The movements' members themselves do not necessarily think of themselves as being related.

3. In both Masonry and Theosophy, the term 'lodge' is used interchangeably to refer to a building and the group of people who meet there. To avoid confusion, I will refer to the physical structure as a 'lodge building'.

4. Cooper (1986:187-202). 
indications are that it was very shortly after the establishment of the city in 1855 . By 1868 , the movement was sufficiently established to construct a lodge building. This was followed by a second building in 1874 . Today, the Freemasons have an estimated 1200 to 1500 members in greater Pretoria.

The movement was at one stage widespread throughout South Africa, but currently it seems to be concentrated in the major cities. As always, its members maintain certain aspects of their tradition as confidential, but recently the movements seems to have opened up and lifted the veils of secrecy that has long surrounded it. One mass meeting of Masons was attended by women and even by the media ${ }^{5}$

An alternative form of Masonry is the Co-Masonic movement, which differentiates itself from the Freemasons mainly by admitting female members ${ }^{6}$ : our respondents in the CoMasonic movement claimed that the actual rituals in the two groups are identical and that many of their members are in fact ex-Freemasons. In South Africa, the Co-Masonic lodges tend to coincide with Theosophical ones, that is, they are concentrated in the major cities and use the same buildings. There is also a large amount of overlap in membership between the Co-Masons and the Theosophical Society. There are about 400 co-Masons in South Africa, with about 35 of these in Pretoria.

The full title of this movement is The International Order of Co-Freemasonry (Le Droit Humaine). As the French subtitle suggests, it was founded in France as a separatist movement from the Freemasons. This occurred in 1875, and according to our informants, the issue of admitting female members was precisely the issue over which the split occurred. The movement was established in South Africa in Johannesburg during the early 1900's and in Pretoria soon afterwards. We shall use the term 'Mason' to refer to both Free- and Co-Masons.

Like many of these groups, Masonry regards itself not as a distinct religious tradition, but as a spiritual or philosophical adjunct to organised religion. A respondent described it as follows:

Religion, as the term is commonly used, implies several things; a plan of salvation or path by which one reaches the afterlife; a theology which attempts to describe the nature of God; and the description of ways or practices by which a man or woman may seek to communicate with God. Masonry does none of these things. We offer no plan of salvation. With the exception of saying that God is a loving Father who desires only good for his children, we make no effort to describe His nature. And while we open and close our meetings with prayer ... we never tell a man how he should pray or for what he should pray. ... We urge men not to neglect their spiritual development and to be faithful in the practice of their religion. ... Masonry itself makes only a simple religious demand on a man - he must believe that he has an immortal soul and he must believe in God. No Atheist can be a Mason.

\section{Theosophy}

The Theosophical Society was founded in 1875 in New York by the famous and controversial nineteenth century mystic Helena Petrovna Blavatsky and her associate Colonel Henry Steel Olcott ${ }^{7}$. After their demise, the Society was taken over by the equally famous

\footnotetext{
5. Pech (1995).

6. It should be noted, however, that all Co-masons, whether male or female, address each other as 'brother': this illustrates its origins in the all-male group.

7. Leonard (1976:22-23).
} 
Annie Besant, who began her remarkable career as a militant atheist and socialist ${ }^{8}$, but turned to mysticism after her first meeting with Blavatsky ${ }^{9}$. It is hardly an exaggeration to say that if Blavatsky provided the mystical inspiration for the Society, it was Olcott and Besant who put it on a firm organisational footing. Today, the international headquarters are in Adyar, near the city of Madras in India

One of the most extraordinary events in the history of religion in the twentieth century concerned the Theosophical Society. Mrs Besant and CW Leadbeater, another prominent Theosophist, discovered a precocious Indian boy in India named Jiddu Krishnamurti, decided that he was to be the Saviour for this age, and founded the Order of the Star to prepare for his assumption of his destined role. But in 1929, at the age of 36, Krishnamurti dissolved the Order of the Star in the presence of 3000 members, renounced his messianic status and set out on a life-long career of preaching and teaching his message of attention to what is present in the moment. In time, he came to be regarded as one of the most remarkable religious teachers of the twentieth century. So perhaps, Mrs Besant was right after all; perhaps this quiet, selfeffacing man was precisely the kind of saviour needed in our era..

In many ways one the oldest of the 'alternative' traditions in South Africa, the Theosophical Society seems to have established itself in South Africa around 1899, which is the date on the charter of the Johannesburg lodge. Mohandas K (Mahatma) Gandhi, although never formally a member, enjoyed cordial relations with the Johannesburg lodge and is said to have attended an early meeting at which he read a passage from the Bhagavad Gita ${ }^{10}$.

The movement spread rapidly: by the outbreak of the First world War there were lodges in Pretoria, Germiston, Krugersdorp, Cape Town, Durban, Pietermaritzburg, Salisbury (Harare) and Bulawayo and by the end of the war three more had been established in De Aar, Port Elizabeth and Kimberley ${ }^{11}$. The South African Theosophical Society was established in 1909 to serve as a controlling body. Theosophist expansion continued between the world wars, with lodges established in Bloemfontein, George, a special 'coloured' lodge in the Cape, no less than five new lodges around Johannesburg and two in Natal, and one each in Lourenço Marques (Maputo) and Nairobi ${ }^{12}$. Of these, only Johannesburg, Cape Town, Durban, Harare and Pretoria remain, with the Port Elizabeth lodge having closed down only a few years ago.

The Pretoria lodge was established directly after the Second Boer War, in 1903, although the present lodge building was not erected until 1927 - the first building to be wholly owned by a South African lodge ${ }^{13}$.

Few religious traditions can have had a greater impact on Pretoria, relative to their size, than the Theosophical Society. Their lodge building on the east bank of the Apies River has served as a venue for many other religious and philosophical groups, which might otherwise have declined because of the lack of a suitable venue. So popular is this use of the building that on Tuesday evenings, for example, there are two such client groups using the venue, a yoga

8. Melton 1990a.

9. Leonard (1976:110-111).

10. Lean (1949: 35). Gandhi had already come into contact with Theosophy during his years in England; see Chidester (1992: 173).

11. Lean (1949: 24-27).

12. Lean (1949: 28-29).

13. Lean (1949: 28). This building, in a small annex of Skinner street east of the Apies river, was at the time of writing under threat of demolition by an urban development project that seemed set to submerge the entire area beneath a man-made lake. Although most of the concept plans extend the lake only to the edge of the society's property, there is nevertheless great pressure on them to sell. 'We are now discussing in the committee whether we should have this place declared a national monument or sell it and buy a new place somewhere else.' 
group in the main hall and a Buddhist group in the library.

This function of the lodge building has in recent years been expanded by the holding of open days, at which activities as diverse as palmistry, aromatherapy and astrology are practised at little stalls in the lodge's main hall, next to other stalls that sell crystals, books, vegetarian food and other alternative material. Simultaneously, a series of lectures would typically be conducted in the library. The author attended the first such open day, in November 1994. It was clear to see not only how the lodge building serves a large collection of movements, but also that many of the people attending the open day, though not Theosophists themselves, were quite familiar with the building and with the leading figures of the Theosophical Society in Pretoria.

To some degree this has been an accident of geography - when it was built, it stood on the very outskirts of Pretoria, but the city's expansion since then has caused the location to be just outside the central business district. This central location not only makes it an ideal place for small religious groups to meet, but the price of land in the area makes it unlikely that such a small group could ever attempt to build there again. This having been said, however, it must be stressed that a major factor in the lodge's popularity has been the Theosophists' very open and accepting attitude to other religious traditions. This openness is an integral part of Theosophical teaching. Officially, the Theosophical Society claims to have no dogma of any kind: all religions are studied and all Holy Books accepted; its motto is 'there is no religion higher than Truth'. Or, as Blavatsky put it:

The Society, as a body, has no creed, as creeds are but the shells around spiritual knowledge; and Theosophy in its fruition is spiritual knowledge itself ... ${ }^{14}$. This is borne out by the great variety of public lectures presented every week by the Society.

For the committed Theosophist, however, the works of Blavatsky and Besant take on at least a semi-canonical character. Some of Blavatsky's teachings, such as acceptance of the theory of reincarnation and the power of thought ${ }^{15}$, are still taught widely within the society, but others, like the theory of the sunken continent of Lemuria, while still officially part of Theosophy, have been allowed to diminish in prominence. The Theosophical Society seems to have accepted influences from many different quarters. Among these are the occult, psychic and spiritualist traditions of the nineteenth century as well as Buddhist and Hindu influences. Blavatsky ${ }^{16}$ claims that Theosophy can trace its antecedents to ancient Egyptian and Hellenistic philosophies and mystery religions. Besant also claimed Giordano Bruno as a precursor of Theosophy ${ }^{17}$.

\section{The Liberal Catholic Church}

The Liberal Catholic Church was, until a few years ago, one of the movements that had a close relationship with the Theosophical Society in that it rented one of the Society's premises next to the lodge building. In fact, the Liberal Catholic Church has a long history of association with Theosophy. Its founding in 1916 was at least partly influenced by the circulation of Theosophical ideas within Catholic circles. Although the church was founded by Arthur Harris Matthewe in 1916, in England, it traces the Apostolic succession of its priesthood through the Old Catholic Church of Utrecht in the Netherlands, which has been independent of Rome for over two centuries. Doctrinally, it attempts to combine the sacramental and ceremonial nature

\footnotetext{
14. Blavatsky (1981: 16).

15. Theosophical Society in South Africa (1948).

16. Blavatsky (1981: 6-7).

17. Besant (1913).
} 
of the Catholic tradition with the tradition of free enquiry of Protestantism. In this, the church actually goes much further than most Protestant thinkers would care to do: for instance, the doctrine of original sin is re-interpreted in terms of reincarnation and karma. Truly a 'liberal' interpretation! In Afrikaans, however, the church is called the 'Vrye Katolieke Kerk', and thus the 'liberal' part of the church's name should really be understood as meaning 'free' rather than 'indulgent'.

The church's early beginnings in South Africa have unfortunately not been recorded, but it appears to have been established sometime before the second World War. By 1937, it had been established in Pretoria. Today there are some 500 members in South Africa, of which perhaps ten percent live in Pretoria, "but it is typical of our church that there are a lot of people who attend but who do not join formally because they just cannot cross that threshold, or because they think it's just too much trouble'.

This, we found, is a common phenomenon with religious groups outside the religious mainstream - there is a small core of committed members who show up regularly, and a much looser circle of hangers-on who do not formally join the group. For example, the Pretoria lodge of the Theosophical Society claims about 300 members, of which about 120 are fully accredited and active. This makes it the largest lodge in the country - our informant estimated that the other three lodges had between 30 and 45 active members each.

\section{The Rosicrucian Movement}

Like the Masons, the Rosicrucians are a semi-secret society dedicated to the preservation of arcane knowledge. They are, however, somewhat more assertively missionary-minded: advertisements for the Ancient and Mystical Order Rosae Crucis (AMORC) are a common sight in South African newspapers and magazines. Like Theosophy and Masonry, it is not quite a religion in the classical, institutional sense of the word. Like them, it puts itself forward rather as a loose association of philosophically and spiritually inclined individuals: 'It is not a religious society - it is a philosophical society that acknowledges the concept of a single God to whom everybody relates'. It is certainly older than all the other movements except possibly Masonry: the earliest literary reference to the 'Order of the Rosy Cross' was in 1614, and it looks beyond this to a mythical founder named Christian Rosenkreuz who lived in the fourteenth and fifteenth centuries. However, the history of Rosicrucianism as we have it today starts only in 1858, when Paschal Beverly Randolph started to build up a Rosicrucian organisation in America. ${ }^{18}$ This was the start of a confusing period in which a number of Rosicrucian organisations were founded. Today, by far the most influential of these is AMORC, founded by H Spencer Lewis in 1925. By the 1940s, a small pronaos, or Rosicrucian study group, seems to have been active in Pretoria.

Like Masonry, Theosophy and the Liberal Catholic Church, Rosicrucianism is a link between our century and the Qabalistic, Hermetic and Gnostic traditions of past ages. Its link to Asian spirituality is far more vague than that of, say, Theosophy. It is positioned in the western 'occult' tradition. Yet, in its effects, it shows a remarkable similarity to the other movements discussed here. Like them, it rejects the hard, materialistic worldview of nineteenth century scientism in favour of a fluid, dreamlike world in which 'symbols' and 'things' become interchangeable realities, a world in which a given ritual, performed exactly as prescribed, can have effects vastly beyond their apparent import. One explanation of the role of alchemy in Rosicrucianism, for instance, reads as follows:

18. McIntosh (1980: 19, 129-30). 
Q. Do the Rosicrucians still practice the art of alchemy or transmutation of base metals into gold?

A. In some of the higher lodges of the organization where complete laboratories are maintained for testing and proving many of Nature's fundamental laws, the art of transmutation has been tested and a small amount of gold made from baser metals after a great many hours of diligent work, and at a tremendous cost, out of proportion to the value of the gold manufactured. In France, one of the great laboratories of the Order has been very successful in demonstrating to the scientific world the feasibility of the Rosicrucian principles of alchemy. The Rosicrucians have always been accused of being the makers of gold because throughout the history of the organization it appears that its members and its branches are always well qualified to meet their financial obligations and to enjoy many of the luxuries of life. The progress and advancement which the members make as they go through the higher teachings of the Order impress strangers with the idea that some means of securing material wealth is given to the students of the organization. The real art of alchemy practiced by every Rosicrucian organization and every member of the organization consists of transmuting the baser metals of a material, mental, and spiritual nature into the pure gold products of efficiency in action, prosperity in result, and happiness in attainment. This is the greatest of all the processes of transmutation and enables each member to successfully master his own problems and bring about such realizations of his dreams as may seem miraculous or mysterious to the uninitiated. $^{19}$

But although Rosicrucianism shares many ingredients with Masonry, it differs in one crucial respect, and that is that it is assertively missionary-minded. As mentioned above, Rosicrucian advertisements appear regularly in South African magazines. Rosicrucian stalls also appear regularly at alternative life-style fairs. Nevertheless, Rosicrucianism does not demand a complete change of the new member's life-style: it seeks to co-exist alongside the established religions, as a metaphysical or philosophical adjunct to them. An informant described it as follows:

Anybody who wishes to join can associate and belong to it - whether they are male or female, Catholic or Jewish or otherwise. And then they can interpret for themselves the basic precepts which are discussed and decide for themselves where they fit in and what is acceptable to them or not. And if you are a Methodist, it can be said that you will be a better Methodist for having looked into the discourses, or a better Jew or whatever. Even the Northern Buddhists could associate with the Rosicrucian Order without any problem at all. We are a fraternity of people who are searching for the truth of the universe just as much as everybody else is.

\section{The Spiritualist Movement}

Like so many of these traditions, Spiritualism can be seen to have not merely a history, but a much longer prehistory. In a sense it is both the oldest and one of the youngest of the faiths discussed in this article. Spiritualism in the general sense of attempting to make contact with the spirit of a deceased person is an almost universal feature of religious practice. It can be found in sources as far removed from each other in space and time as the Old Norse poem Voluspa, in which the god Odin raises the spirit of a seeress to find out what the future holds, to the Bible (I Samuel 28), in the episode where Saul contacts the spirit of his former mentor, 
Samuel, through a medium in Endor. The desire to know that death is not the end of everything seems to be central to the religious impulse itself, and to validate this belief while simultaneously receiving a comforting message from a loved one is a religious experience of immeasurable antiquity.

Modern, wester Spiritualism, however, traces its roots to a specific set of events in 1848, when the Fox sisters of upstate New York started to produce strange rapping noises. Forty years later, they would confess to having faked these sounds, but by then the Spiritualist movement had spread like wildfire across the United States and Great Britain. In any case, by no means everything that has since been produced in the name of Spiritualism can be attributed to fraud. The 'physical mediums' of the early years gradually gave way to a new set of mediums, who made no claim to producing audible or visible phenomena, but who did claim to be in contact with the spirits of the deceased. With this change came a transformation of Spiritualism from an activity of isolated mediums and their followers to the establishment of a Spiritualist Church mainly along Protestant lines, but with the readings of a medium added to the order of service. A seminal moment in this process came in 1893, when the National Spiritualist Association of Churches was founded in the United States.

Spiritualism probably reached South Africa by the late 1880 s. The first Spiritualist group in Pretoria was founded in 1930 by Ms Annie Ross. There was a Spiritualist presence in the Gauteng area before this, though - on December 15 1904. the Pretoria News recorded the presence of delegates from the Johannesburg Society of Spiritualists at the funeral of expresident Paul Kruger.

Spiritualism in Pretoria has seen a sharp decline in popularity since its heyday in the thirties, when there were three Spiritualist churches in the city. Today, just one remains, but like the other movements in this group it shows signs of a modest revival, with increasing numbers of young people at its services. Spiritualism also lives on in its offspring, 'channelling'. This part of New Age ritual has expanded the old Spiritualist territory by claiming to be in contact not merely with the spirits of the dead, but also with extraterrestrials, dolphins and divine beings that have never appeared in human form.

Spiritualist beliefs seem quite diverse, with no one theology to explain the supposed contact between medium and spirit. For example, our informant told us that belief in reincarnation was quite widespread among Pretoria Spiritualists, but was not regarded as an article of belief by the Spiritualist Church. Spiritualist beliefs seem to range across quite a wide continuum, with various amounts of eastern and gnostic ideas overlaying a basically western theistic structure. Our informant also recognised links to the various types of communication with the ancestors in African religion, but little contact between these two groups seems to exist.

\section{Christian Science}

In Pretoria, this is probably the most successful of the movements discussed in this article, successful in the sense that it has established itself as a respectable religious option in the collective mind of mainstream Pretoria. Doctrinally, it is also the closest to mainstream Christianity, in fact Christian Scientists regard themselves as perfectly orthodox Christians even if that opinion is shared by few members of mainline churches.

But the Christian Scientist nevertheless lives in a somewhat different world from the conventional Christian. If pressed, almost all pious Christians would admit that prayer is an efficacious method of warding off sickness and promoting health. But to the Christian Scientist, this is not an incidental side-effect but one of the main messages of the Bible. While the Christian Scientists see their methods of healing as more refined than and superior to that 
practised in the African Indigenous Churches, the similarity of emphasis between the two traditions leads us to speculate that this is perhaps the one organisation within this group of religious traditions that is poised to make a large impact on black Pretoria. Indeed, there already is at least one 'registered practitioner' (that is, a Christian Science healer) in Atteridgeville. Although the assembly there is thus far only a 'society ' rather than a full-blown 'church', it shows great promise for the future.

The official title of the church is the Church of Christ, Scientist and it was founded in late nineteenth century America by Mary Baker Eddy, whose book Science and Health, with key to the scriptures is regarded as the foundational statement of Christian Science doctrine. This book is regarded within the church as being the 'comforter' mentioned in John 14-16, which shows the importance attached to this work in Christian Science circles. The church was formally founded in 1879 in the city of Boston. Today, it claims 2400 branch churches in 63 countries. In South Africa, the church was in fact started in Pretoria, in 1907. After being housed in a number of locations, the First Church of Christ, Scientist, Pretoria was established in Du Toit street, Sunnyside in 1922. The next oldest Christian Science congregation in South Africa is in Johannesburg. As early as 1929 , members in the east of the city decided to establish a separate branch, which was to evolve into the Second Church of Christ, Scientist, Pretoria, with its church building in Hatfield. In recent years, a Christian Science group has also been established in Centurion. Proposed road construction in the area, however, necessitated the sale of the First Church to the Pretoria City Council. The last Christian Science service there was held in May $1993^{20}$. At the time of writing, the proposed road has not yet been built, and the building has retained its religious character - it is currently inhabited by a Muslim social service organisation.

\section{Who joins the early alternative movements?}

In Pretoria, all these groups are currently quite small, with the Freemasons probably the largest in this group. Moreover, the overlapping membership of some of these movements tends to make them seem collectively a larger force than they actually are. However, they are all overwhelmingly white, middle-class and urban organisations, which has in the past given them perhaps more influence on the course of the city's history than their numbers alone might have justified. Whether this will hold true in the Pretoria of the future remains to be seen.

English is the overwhelming language of choice in all these movements. Somewhat surprisingly, as much as fifty percent of a group's membership may be Afrikaans-speaking in origin and in current home-language status, but nearly all of our respondents stated that services in Afrikaans had been attempted some years back, but had to be abandoned for lack of interest. This is an unusual situation: in other traditions, people have tended to be attracted to religions where their native language was the main form of communication. Perhaps this shows that the people who are attracted to these movements are already somewhat alienated from mainstream society. Of course, it could also mean that they are sufficiently cosmopolitan in outlook to have grown beyond a narrow linguistic nationalism. This is certainly an intriguing area for future research.

The early eastern-alternative movements in Pretoria are an overwhelmingly white phenomenon. The Theosophical Society has attracted a few Indian members from time to time, and there are some black members of the Liberal Catholic Church, but these are exceptions to the rule. Among this group of movements, it is probably Christian Science that has made the

20. First Church of Christ, Scientist, Pretoria 1993. 
greatest advances outside the white community. In principle, however, all of these movements are open to all, and in the past they have distanced themselves from apartheid as far as their limited size has allowed them to.

One important factor in this group of movements is the prominent role played by women. The all-male Freemasons would naturally be an exception here, but among the Co-Masons, who do admit female members, women assume leadership roles equal to that of the men. The role of women seems to be strongest in those movements that were founded by women: Theosophy by Madame Blavatsky and Christian Science by Mary Baker Eddy.

In the Theosophical lodge in Pretoria, the numbers of men and women are roughly equal. Women also serve in the committees and as office-bearers on an equal basis. But this does not negate the near-universal norm that female attendance at religious gatherings outstrips that of the men. The situation at the Pretoria lodge is seen as an anomaly even by our respondents:

In other lodges the tendency is to have more women than men, because they can feel, they are more intuitive. They see the higher theosophy, whereas men have to reason it out.'

The Liberal Catholic Church differs from the norm in this group in that it ordains only males into the priesthood. Our respondent explained the rationale for their policy as follows:

We see a strict division between the masculine and the feminine aspects. It concerns the esoteric view, and that makes it hard for us to discuss this with other churches that don't maintain an esoteric view. When you look at the consecration of the bread and the wine, we regard the chalice as a feminine symbol, it is the womb in which new life is created. Then the priest takes the hosti, a round slice of bread, which we see as a symbol of masculinity. And while reciting a certain prayer he drops a small piece in the chalice. Now we see this as symbolic of human fertilisation. So, it's logical that only a man can take this small piece of bread and drop it into the chalice.

While it is dangerous to generalise on such small samples, our general impression of these movements was that they were currently dominated by people in their fifties and sixties. All, however, seem have attracted a new audience of young people in their late twenties and early thirties, especially in the last ten years or so. The generation in-between is largely missing from the services and meetings of these movements. This development was most pronounced in the Theosophical Society and least in the Liberal Catholic and Christian Science Churches, which have a more balanced distribution of members of different ages. Until recently, the Theosophical Society worldwide seemed to be in a long, slow decline from its high degree of popularity in the early part of the century. Meetings and lectures were dominated by middleaged and even old people. The same was true of the Pretoria lodge. In the last ten years or so, however, the Society has undergone something of a renaissance, with increasing numbers of younger people attending public lectures and some eventually joining the Society. However, a generation gap is still felt to exist:

The youngsters today ... want phenomena, they want excitement. They want to become perfect in five easy lessons even if it costs five thousand Rand. But they don't want to work, and study and experience within.'

A similar situation was found in the other movements. Whenever we attended a service of any organisation within this group, we found ourselves among a group that included some quite old and some relatively young people, with very few of the in-between generation present. It should be said, however, that we were unable to attend meetings of the Masons and Rosicrucians. It may well be that these movements have more middle-aged members.

Our assessment of these groups also maintains that they tend to attract people from the 
middle and especially upper-middle classes. Again, this is a subjective assessment, but it is consistent not only with the racial composition of the membership, as this manifests itself in South Africa circa 1995, but also with the locality of their buildings and with our experiences of related groups country- and worldwide. Their level of education also seems to be above average, with a surprising number, for such small groups, of the leadership working as university lecturers in a variety of disciplines. Among the people we interviewed were two professors and an ex-engineer, and all the others seemed to have had a university education.

\section{Joining and leaving the early alternative movements}

In the three Christian-oriented movements in this group, the Liberal Catholic church on the one hand, and the Spiritualist and Christian Science churches on the other, the method of joining closely resembles that found in, respectively, the (Roman) Catholic and conventional Protestant churches. This involves the common Christian rituals of baptism, confirmation etc. The other movements, having esoteric elements built into their structures, require the member to go through a progressive series of initiations or other forms of institutionalised spiritual ascent, the most elaborate of which are the thirty-three degrees of Masonry. Details of these are confidential, though a thorough search through widely available literature will reveal a fair amount of information on them.

As can be expected with religious organisations that are generally tolerant of diverse philosophical and religious standpoints, these groups rarely discipline or expel members. Their comments were as follows:

Not unless they make themselves very objectionable and are trying to break down the principles of the society. This happens very rarely. I can't think in all the years I've been here or in all my dealings with the other lodges, of an occasion where anybody was asked to get out. Even if a person is somewhat objectionable, we are supposed to learn tolerance. You can't learn tolerance with nobody around. (Theosophical Society).

Once you are baptised, you are a member forever, until you die. Of course, if we never see you, you are no longer regarded as a member of a particular parish. But that doesn't change the fact that you are still a member, still a part of the body of Christ. (Liberal Catholic Church)

\section{Organisations, links and networks}

One unique characteristic of Christian Science is that members are encouraged to register as members both of the local congregation and of the Mother Church in Boston. This, together with the practice of disseminating the same material for simultaneous sermons and reflections throughput the world, leads to a high degree of solidarity among the church's members. It will be remembered from Part I that a similar pattern exists in the Jehovah's Witnesses. Rosicrucianism is also a highly internationalised movement, with much emphasis on the study material sent out from the headquarters in California. The bishop of the Liberal Catholic Church in Pretoria was, at the time we interviewed him, presiding bishop of the church worldwide. In fact, none of these organisations is a purely local phenomenon; they all belong to international umbrella bodies.

Similarly, each of the movements is part of a national body that administers the movement's activities in South Africa. However, the small size of these groups and the cost of maintaining international and national links has meant that, in practice, their Pretoria congregations have enjoyed a relatively high degree of autonomy.

None of these organisation maintains anything like a seminary in Pretoria or indeed, in South Africa. Training of office-bearers is carried out within the organisation and members of 
committees and other structures may be elected democratically, but usually coincide with members who have advanced the furthest in the church hierarchy or who have undergone the higher esoteric initiations.

As we have seen, the Co-Masonic movement, Liberal Catholic Church and Theosophical Society are quite closely interlinked, with a considerable overlap in membership. Also, one would not be surprised to see Freemasons and Rosicrucians also taking an interest in one or more of the other groups. This, however happens informally and on an individual basis. Besides belonging to their respective national and international bodies, these movements do not belong to formal interdenominational or interreligious organisations.

Within most of the groups discussed here there exists a clear division between the 'open' meeting which is open to all, whether or not they are members, and the 'closed' meeting, a meeting involving only a small group with the requisite initiations, or alternatively a single member and a church official with a specialised function. This distinction is not universal: the Liberal Catholic Church has only 'open' meetings, the Masons generally only conduct 'closed' ones. Rosicrucian meetings are generally 'closed', but their literature is widely available.

The Theosophical Society holds public lectures on Sunday evenings, with a wide variety of guest speakers ${ }^{21}$, and also lessons in basic Theosophy during the week. However, it also has an esoteric study group that consists of persons who have attained a high degree of initiation into the Theosophical ranks. This group's meetings are not advertised and one may join it only by invitation. It meets regularly for sessions of presumably, meditation and ritual One respondent explained, 'You've got to be a member of the society in order to be eligible to join the esoteric group, but the esoteric group doesn't interfere with the work of the society.' Informal observation quickly revealed, however, that the esoteric group includes virtually the entire leadership of the lodge. This should not be taken as a sign that the esoteric group acts as a kind of 'shadow cabinet' - no evidence points to this. What it does indicate is that spiritual advancement and involvement in church administration go hand in hand in small groups like these: there is no separate caste of full-time church administrators.

The Christian Science and Spiritualist Churches hold regular services on Sundays, but the raison d'etre for these organisations seems to lie not in these services, important as they are, but in the member's personal interview with a Christian Science healer (a 'registered practitioner') or Spiritualist medium. This interplay between the public and the private, the exoteric and the esoteric, is of course not unknown elsewhere in the religious world - something similar happens wherever a minister counsels a church member privately after delivering a sermon to the whole congregation. But in this group of faiths, the interplay between public and private takes on a greater significance. Here the private or small-group meeting is not ancillary to the main event of communal worship, but becomes an intimate part of the tradition's very reason for being.

The small size of these movements prevents them from carrying out much in the way of social involvement. The one exception in this regard is the old-age home currently under construction by the Christian Scientists. An earlier attempt at social involvement by the Theosophists, embodied in an organisation called the Theosophical Order of Service did not last in this country: 'It exists, other countries are doing it, but not in South Africa.'

The Freemasons, too, have an old-age home in Pretoria, which admits both Masons and nonMasons. They also maintain a bursary fund for the children and grandchildren of needy members.

21. These guest speakers are not necessarily Theosophists and only occasionally is Theosophy the subject matter of such a lecture. Lecture topics vary from Hinduism to spiritual healing to (unconventional interpretations of) Christianity. The author has been an occasional lecturer at the lodge for the past few years, usually on the subject of Buddhism. 
One distinct characteristic of all organisations in this group is their tolerant attitude to other religions. None of them claim to have found the only possible way, although each regards itself as perhaps the most inclusive. There are, however, differences in emphasis: one respondent from the Theosophical Society typified this group when he stated that 'Our members are not restricted from attending other churches or religious organisations', and indeed, at any public lecture in the Theosophical Society lodge building on a Sunday night one will encounter people who will admit to being members of mainline Christian churches, even the Dutch Reformed Church, although one respondent stated that the liberal Catholic Church was the choice of most Theosophists who still belonged to other religions. The mainline churches themselves, however, seem to be, or perhaps choose to be, ignorant of this fact: we have yet to receive a questionnaire or conduct an interview in which a Christian minister, other than those from the Liberal Catholic Church, admits that some of his or her flock also attend meetings of the Theosophical Society. The same situation is true of the Masons:

Freemasons do not look upon their organisation as a church, but most ... belong to an established church. ... Freemasons may well review and consider that portion of their petition toward becoming a Freemason - to the Muslim this means, Allah; to the Buddhist it means Buddha; to the Confucian it means Confucius and to the Christian it means God ... Freemasonry does not recognise all religions as equal. To do so would require a careful investigation, evaluation and judgement of all faiths, which Freemasons have never done. Instead, Freemasonry recognises the equal right of all men to worship God as they see fit.

Naturally, enough, a religious organisation with a built-in tradition of tolerance towards other religions will not tend to conduct an assertive missionary campaign. While all these organisations do advertise their meetings in one way or another, all do so in an essentially passive way. Their objective is simply to inform the public of their activities and then to let those who attend out of curiosity join if they wish.

At one stage we used to advertise our Sunday evening lectures, but we stopped that, because they started charging us for the ads, and it became rather expensive. So now we just put up some posters. People see a poster and they come. If they like the place, they stay. If not, they don't come back again.

Some of these churches have experienced animosity from the wider religious community of Pretoria in the past. One Theosophist told us that 'A Baptist Church minister once told his congregation: 'The devil lives in Pretoria and his address is 424 Skinner Street'. There does seem to be a feeling among Theosophists that, even if they are not directly being persecuted by more conservative elements in Pretoria society, ' ... they won't allow us to talk. Particularly those of us who are in government jobs - we have to be careful what we say'. At the moment, however, they are a tolerated if not fully accepted part of Pretoria society. To some extent, this may be the result of their long tenancy in the city. A more immediate factor, however, may be the rise of the 'New Age Movement' as the most visible religious alternative, even threat, in the eyes of more conservative religious people.

\section{Future prospects}

From our perspective, all of these movements are stuck in an anachronism: the hard empiricism of nineteenth century science to which, in their various ways, they are reactions, but from which they also took certain themes, is no more. Yet what answer do they have to the burning intellectual issues of the twentieth, and indeed the twenty-first, century?

Most of them have seen a precipitous decline in popularity since the turn of the century, yet many are now experiencing a modest revival, perhaps as a new fin-de-siecle mood of pessimism 
sets in. Certainly, they all need to break out of their narrow appeal to white, middle-class urbanites if they wish to expand their circle of influence. But in the end, perhaps sheer numbers are not what these groups are really about. In one way or another, they all have a distinct gnostic character, stressing understanding and spiritual growth rather than a simpler, more direct faith. Perhaps their gift to Pretoria lies not in how many of them there are, but in the very fact of their existence, in the manner they paved the way for the emergence of movements even further removed from the city's religious mainstream. Simply by being there, these movements have created the possibility of a religious pluralism that extends to the 'left' of consensus religion in Pretoria, as well as to the 'right'. 


\section{BIBLIOGRAPHY}

Besant, A 1913. Giordano Bruno. Adyar: Theosophical Office.

Blavatsky, HP 1981. Basic questions about Theosophy. Bangalore: Theosophy Company.

Cooper, AA 1986. The Freemasons of South Africa. Cape Town: Human \& Rousseau.

Chidester, D 1992. Religions of South Africa. London: Routledge.

First Church of Christ, Scientist, Pretoria, 1993. The growth and history of the Christian Science movement in Pretoria, 1903-1993. [sl]

Leonard, ML 1976. Madame Blavatsky: medium, mystic and magician. London: Regency.

Lean, P 1949. Fifty Years of Theosophy. The golden jubilee of the Johannesburg lodge. Pretoria: Institute for Theosophical Publicity.

Lewis, HS 1929. Rosicrucian questions and answers, with complete history of the Rosicrucian Order. San Jose, Rosicrucian Press.

McIntosh, C 1980. The Rosy Cross unveiled. The history, mythology and rituals of an occult order. Wellingborough: Aquarian Press.

Melton, A 1990a. The origins of Theosophy: Annie Besant - the atheist years. New York: Garland.

Pech, K 1995. Wind of change blows at last up the furtive Freemasons' aprons. Sunday Independent, October 8 1995, p. 11.

Theosophical Society in Southern Africa. 1948. Theosophy in a nutshell (an introduction to Theosophy). Pretoria: Institute for Theosophical Publicity in South Africa.

\section{OTHER SOURCES}

Bate, OH 1972. The lodge De Goede Hoop. [sl].

Besant, A 1927. Duties of the Theosophist. Adyar: Theosophical Publishing House.

Church of Christ, Scientist, 1993. Media guide to Christian Science. Boston: Committee on publication of the First Church of Christ, Scientist.

Heindel, M 1933. Blavatsky and the Secret Doctrine. Los Angeles, CA: Phoenix.

Luytens, M 1990. The life and death of Krishnamurti. London: John Murray.

Melton, A 1990b. Theosophy I: the inner life of Theosophy. New York: Garland.

Melton, A 1990c. Theosophy II: Controversial and polemical pamphlets. New York: Garland.

Melton, A 1990d. Spiritualism I: Spiritualist thought. New York: Garland.

Melton, A 1990e. Spiritualism II: The movement. New York: Garland.

Porter, KH 1972. Through a glass darkly. Spiritualism in the Browning circle. New York:

Octagon.

Ryan, C J 1975. HP Blavatsky and the Theosophical movement: a brief historical sketch. San Diego, CA: Point Loma Publications.

Time-Life Books 1989. Spirit summonings. Amsterdam: Time-Life.

Van Alphen, J 1991. Catechism. 99 questions and answers on the Liberal Catholic Church. London: St Alban Press. 


\section{OTHER WORKS IN THE SERIES 'RELIGION IN PRETORIA'}

Clasquin, M \& Molobi, VS 1994. Directory of religious organisations in the Greater Pretoria area. Pretoria: C B Powell Bible Centre.

Clasquin, M 1995. Researching a city's faiths - methodological notes from the coalface. Religion \& Theology 2:3 pp 256-273.

Clasquin, M 1997. The lotus in the lion's den: Hinduism in Pretoria. Journal for the study of religion: 10/1, March 1997.

Clasquin, M. Alternative religion in Pretoria, Part I: New forms of Christianity. Scriptura 68 (1999).

Clasquin, M. The Jewish experience of an Afrikaner city. Religion \& theology: in process.

Clasquin, M. The prophet's children in Pretoria: Islam in the heart of Afrikanerdom. Article in preparation:

Krüger, JS. Sweeping whirlwinds: religion in Pretoria. Book in preparation. 